\title{
Optimal mud to sand ratios in sediment for sea cucumber aquaculture as revealed by carbon stable isotopes
}

\author{
Yi-Ran Hou ${ }^{1}$, Yong-Jun Sun ${ }^{2}$, Qin-Feng Gao ${ }^{1, *}$, Shuang-Lin Dong ${ }^{1}$, Bin Wen ${ }^{3}$, \\ Hai-Bo $\mathrm{Yu}^{4}$ \\ ${ }^{1}$ Key Laboratory of Mariculture, Ministry of Education, Ocean University of China, Qingdao, Shandong Province 266003, \\ PR China \\ ${ }^{2}$ Research Office, Homey Group Co., Ltd., Rongcheng 264306, PR China \\ ${ }^{3}$ College of Fisheries and Life Science, Shanghai Ocean University, Shanghai 201306, PR China \\ ${ }^{4}$ College of Animal Science and Technology, Northwest A \& F University, Yangling, Shanxi Province 712100, PR China
}

\begin{abstract}
Sediment, which is central as a sink for organic material and nutrient cycling, provides habitat for feeding, resting, and nesting of sea cucumbers in aquaculture systems. We conducted a 2 mo experiment to investigate the optimal sea mud to sand ratios in sediment for sea cucumber Apostichopus japonicus (Selenka, 1867) aquaculture. Sea mud $(<0.08 \mathrm{~mm})$ and sand $(0.08-0.5 \mathrm{~mm})$ were used to prepare 5 different sediment formulations with different sea mud:sand ratios: $3: 1,1: 1,1: 3,1: 0$, and 0:1. Sea cucumbers were cultured in 20 fiberglass tanks (50 l) with $5 \mathrm{~cm}$ thick sediment spread on the bottom. Results showed that the specific growth rate of sea cucumbers and the contribution of the seaweed Sargassum muticum to food uptake by sea cucumber in the 3:1 ratio group were significantly higher than in the 1:0, 0:1, and 1:3 ratio groups, while no significant differences were observed between the 3:1 and 1:1 ratio groups. Furthermore, the total nitrogen, total organic carbon, and ammonium contents of the 1:1 and 3:1 ratio groups significantly decreased with time. These findings suggest that sea mud:sand ratios of 1:1 and 3:1 are optimal in sediment for $A$. japonicus aquaculture and effectively promote growth and bioremediation.
\end{abstract}

KEY WORDS: Apostichopus japonicus $\cdot$ Sediment $\cdot$ Sea cucumber aquaculture $\cdot$ Carbon stable isotope

\section{INTRODUCTION}

The sea cucumber Apostichopus japonicus (Selenka, 1867) (Liao 1980), which belongs to the Echinodermata, Holothuroidea, is an epibenthic and temperate species inhabiting coastal areas of Asia (Yang et al. 2005). Among the 1100 known sea cucumber species in the world, A. japonicus is one of the most commercially valuable aquaculture species (Okorie et al. 2008) and has long been exploited as an important fishery resource in Russia, China, Japan, and

${ }^{*}$ Corresponding author: qfgao@ouc.edu.cn
Korea (Sloan 1984). Aquaculture of A. japonicus has rapidly expanded in China over the past $20 \mathrm{yr}$ (Chen 2004, Xia et al. 2012). The total production of $A$. japonicus exceeded $201000 \mathrm{t}$ in 2014, representing a $3.8 \%$ increase relative to 2013 (MOAC 2015).

Sea cucumbers, being deposit feeders, mainly ingest microorganisms, organic detritus, and animal feces including their own feces (Yingst 1976, Moriarty 1982, Uthicke \& Klumpp 1998). A. japonicus plays an important role in the removal, recycling, and repackaging of nutrients, especially of organic

(C) The authors 2017. Open Access under Creative Commons by Attribution Licence. Use, distribution and reproduction are unrestricted. Authors and original publication must be credited. 
matter (Jumars \& Self 1986). Their trophic position and ability to process sediment enriched and affected by aquaculture activities has led to strong interest in their use in integrated multitrophic aquaculture systems (IMTAs) worldwide (Zamora et al. 2016). In IMTAs, A. japonicus, being an important production unit, can remove pollutants from the sediment and promote the recycling of aquaculture waste (Yuan 2005). Kang et al. (2003) observed that in co-culture with the abalone Haliotis discus hannai in a static culture system, $A$. japonicus could effectively reduce the food residue and feces in sediment and improve water quality. In a suspension aquaculture system with filter-feeding bivalves, co-cultured A. japonicus could effectively utilize particulate waste and act as a scavenger with great potential for bioremediation (Yuan et al. 2012). This sea cucumber is therefore not only an important economic aquaculture species, but also an important potential species for bioremediation in aquaculture systems (Yuan 2005).

Sediment and the overlying water column constitute habitat for sea cucumbers in aquaculture ponds. Sediment, which is central as a sink for organic material and nutrient cycling, provides habitat for feeding, resting, and nesting of sea cucumbers. The residual materials, mainly uneaten food, feces, and organic detritus, accumulate at the sediment-water interface by settlement, complexation, and adsorption. A number of studies on holothurians have demonstrated selectiveness for particle size and habitat (Rhoads \& Young 1971, Hauksson 1979, Roberts 1979, Sloan \& von Bodungen 1980, Wiedemeyer 1994, Dar \& Ahmad 2006). Zhou et al. (2008) determined that approximately $60 \%$ of the intestinal contents of wild $A$. japonicus consisted of sand particles ranging in size from 0.0625 to $0.5 \mathrm{~mm}$. However, Zhao \& Yang (2010) reported from a field investigation that $90 \%$ of the intestinal contents of the $A$. japonicus gut were fine particles $(1-80 \mu \mathrm{m})$.

Stable isotope analysis had been widely used as an effective tool to trace food sources (Fry 2006, Michener \& Lajtha 2008, Sun et al. 2013) and the fate of fish-farming waste (Sarà et al. 2004, Yokoyama 2013). In the present study, we used stable isotope analysis to reveal the utilization and assimilation of the seaweed Sargassum muticum. We also used sea mud $(<0.08 \mathrm{~mm})$ and sand $(0.08-0.5 \mathrm{~mm})$ to produce different sediment formulations with different sea mud:sand ratios. The interactions between sea cucumbers and each specific sediment were investigated to find an optimized sediment formulation for A. japonicus aquaculture.

\section{MATERIALS AND METHODS}

\section{Sediment preparation}

The compositions of experimental sediments with 5 different ratios of sea mud and sand are presented in Table 1. The experimental sea mud and sand were obtained from the coastal zone of Qingdao, China. After having dried in the sun, the sea mud was ground and sieved through a $0.08 \mathrm{~mm}$ mesh. Sand was ground and sieved using 0.08 and $0.5 \mathrm{~mm}$ meshes. After being ground and sieved, the sea mud $(<0.08 \mathrm{~mm})$ and sand $(0.08-0.5 \mathrm{~mm})$ were used to prepare 5 different sediment formulations with different sea mud:sand ratios, i.e. 1:0, 3:1, 1:1, 1:3, and 0:1 (represented as M, MMMS, MS, MSSS, and S, respectively).

\section{Culturing experiment}

The experiment was conducted at the laboratory of the Qingdao National Ocean Scientific Research Center, Ocean University of China. The experimental sea cucumber (Apostichopus japonicus) specimens were collected from a local commercial farm. The experimental diets were composed of the seaweed Sargassum muticum, which was dried and ground to pass through a $0.063 \mathrm{~mm}$ mesh. Prior to the beginning of the experiment, A. japonicus were cultured in $50 \mathrm{l}$ fiberglass tanks for $7 \mathrm{~d}$ to acclimatize them to the laboratory conditions. After acclimating, sea cucumbers with initial weights of $7.49 \pm 0.23 \mathrm{~g}$ (mean $\pm \mathrm{SD}$ ) were cultured in glass aquarium tanks $(30 \mathrm{~cm} \times 40 \mathrm{~cm} \times 50 \mathrm{~cm})$ with 5 sediment formulations in 4 replicates for each formulation. The bottoms of all 20 experimental aquarium tanks were covered with $5 \mathrm{~cm}$ sediment, and the tanks were filled with seawater. Sea cucumbers were fed every $2 \mathrm{~d}$ at 16:00 h with experimental diets of $5 \%$ of the body weight. The diets were well mixed with water and evenly poured into every tank. The water tempera-

Table 1. Ingredients of the experimental sediments

\begin{tabular}{|lcc|}
\hline \multirow{2}{*}{$\begin{array}{l}\text { Sediment } \\
\text { Treatments }\end{array}$} & Sea mud & $\begin{array}{r}(\%) \\
\text { Sand }\end{array}$ \\
\hline M & 100 & 0 \\
MMMS & 75 & 25 \\
MS & 50 & 50 \\
MSSS & 25 & 75 \\
S & 0 & 100 \\
\hline
\end{tabular}


ture was maintained at $16.5 \pm 0.5^{\circ} \mathrm{C}$, and salinities ranged from 29 to $31 \%$. Two-thirds of the volume of the water in each tank was replaced with filtered seawater every $2 \mathrm{~d}$. The experiment was conducted for $2 \mathrm{mo}$.

\section{Sample collection}

Before the experiment, 10 sea cucumbers were dissected as initial samples to collect body wall materials for the analysis of carbon stable isotope ratios $\left(\delta^{13} \mathrm{C}\right)$. At the end of the experiment, A. japonicus individuals were starved for $48 \mathrm{~h}$ to empty the gut and then were weighed. After weighing, all A. japonicus individuals in each aquarium were dissected on ice to separate the body walls. All separated body walls were placed in plastic bags and kept in a freezer at $-80^{\circ} \mathrm{C}$. The same was done with sea mud, sand, and the seaweed $S$. muticum samples, before the analysis of carbon stable isotope ratios $\left(\delta^{13} \mathrm{C}\right)$.

During the 2 mo experiment, 3 sampling points were randomly selected in each of the 20 tanks, and 0-1 cm surface sediment samples were collected with a plastic pipe measuring $2 \mathrm{~cm}$ in diameter before the experiment began, and then again during Weeks 2, 4, and 8. All sediment samples from the same tank were well mixed, dried in a lyophilizer (CHRIST LYO Alpha 1-4 LD plus), ground to powder in a mortar to pass through a $100 \mu \mathrm{m}$ mesh sieve, and kept in a freezer at $-80^{\circ} \mathrm{C}$ before further analyses of the total nitrogen (TN), total carbon (TC), total organic carbon (TOC), exchangeable $\mathrm{NH}_{4}{ }^{+}$, and $\mathrm{NO}_{3}{ }^{-}$ concentrations.

\section{Laboratory analyses}

The growth performance of $A$. japonicus in terms of specific growth rate (SGR) was calculated as:

$$
\operatorname{SGR}\left(\% \mathrm{~d}^{-1}\right)=\left(\ln W_{\mathrm{f}}-\ln W_{\mathrm{i}}\right) / t \times 100
$$

where $W_{\mathrm{f}}$ and $W_{\mathrm{i}}$ are the final and initial weights of $A$. japonicus individuals in each aquarium, respectively, and $t$ is the duration of the experiment in days.

Inorganic carbon was removed as $\mathrm{CO}_{2}$ from samples of sea mud $(<0.08 \mathrm{~mm})$ and sand $(0.08-0.5 \mathrm{~mm})$ by adding 1:1 $\mathrm{HCl}$. Then, together with samples of body tissues and the seaweed $S$. muticum, the sand and sea mud were dried at $60^{\circ} \mathrm{C}$ for $48 \mathrm{~h}$ to a constant weight for carbon stable isotope measurements. $\delta^{13} \mathrm{C}$ and carbon content of sea mud, sand, S. muticum, and body tissues of sea cucumbers were determined using an elemental analyzer coupled with an isotope ratio mass spectrometer (EAIRMS, ThermoFinnigan MAT Delta-plus). Results of the stable isotope ratios were expressed in standard $\delta$-unit notation, which is defined as follows:

$$
\delta^{13} \mathrm{C}=\left[\left(R_{\text {sample }} / R_{\text {standard }}\right)-1\right] \times 1000
$$

where $R$ is the ${ }^{13} \mathrm{C}:{ }^{12} \mathrm{C}$ ratio. The values were reported relative to the Vienna Pee Dee Belemnite standard. Glycine was employed as the laboratory working standard and was run every 10 samples. Analytical precision was $\pm 0.1 \%$.

TN and TC concentrations of sediment samples were determined using a FlashEA 1112 Series NC Analyzer. TOC concentrations were also determined using the element analyzer after inorganic $\mathrm{C}$ as $\mathrm{CO}_{2}$ was removed by adding 1:1 $\mathrm{HCl}$ and oven-dried to a constant weight.

The sediment samples were extracted with $\mathrm{KCl}$ solution (2M) to extract exchangeable $\mathrm{NH}_{4}^{+}$and $\mathrm{NO}_{3}{ }^{-}$(Bremner 1965). Sediment samples of $0.2 \mathrm{~g}$ were placed into $50 \mathrm{ml}$ centrifuge tubes and treated with $20 \mathrm{ml} \mathrm{KCl}$ solution (2M), then equilibrated at 25 $\pm 2{ }^{\circ} \mathrm{C}$ in an end-over-end shaker for $2 \mathrm{~h}$ before being centrifuged at $5000 \times g(10 \mathrm{~min})$. The supernatant was then filtered through a $0.45 \mu \mathrm{m}$ glass fiber filter (Whatman GF/C) and determined for $\mathrm{NH}_{4}{ }^{+}$and $\mathrm{NO}_{3}{ }^{-}$ contents.

\section{Stable isotope mixing model and statistical analysis}

For sediment groups $\mathrm{M}$ and $\mathrm{S}$, the 2-source concentration-weighed isotope mixing model was used to evaluate the respective contributions of the sediment ingredient and $S$. muticum to the food uptake of $A$. japonicus (Phillips 2001, Phillips \& Koch 2002):

$$
\begin{gathered}
\left(\delta^{13} \mathrm{C}_{\mathrm{X}}^{\prime}-\delta^{13} \mathrm{C}_{\mathrm{M}}\right)[\mathrm{C}]_{\mathrm{X}} f_{\mathrm{X}, \mathrm{B}} \\
+\left(\delta^{13} \mathrm{C}_{\mathrm{Y}}^{\prime}-\delta^{13} \mathrm{C}_{\mathrm{M}}\right)[\mathrm{C}]_{\mathrm{Y}} f_{\mathrm{Y}, \mathrm{B}}=0 ; f_{\mathrm{X}, \mathrm{B}}+f_{\mathrm{Y}, \mathrm{B}=1}
\end{gathered}
$$

where $f_{\mathrm{X}, \mathrm{B}}$ and $f_{\mathrm{Y}, \mathrm{B}}$ represent the fractions of assimilated biomass $(B)$ of sources $X$ and $Y$, respectively, in the mixture $M .[C]_{X}$ and $[C]_{Y}$ represent the carbon concentrations in food sources $X$ and $Y$. Isotope signatures for the sources were corrected for trophic fractionations as designated by the prime (') symbol.

For sediment groups MS, MSSS, and MMMS, the stable isotope mixing model Isosource procedure was conducted to calculate the contributions of sea mud, sand, and $S$. muticum to the food uptake of A. japonicus (Phillips \& Gregg 2003, Wen et al. 2016). An average fractionation effect of $1 \%$ for carbon isotopes was used to correct stable isotope shifts for 
Table 2. Growth performance of Apostichopus japonicus in different sediment groups. Data are presented as mean $\pm \mathrm{SD}(\mathrm{n}=3$ ). Different letters in the same row mean significant differences (ANOVA with Duncan's test for multiple comparisons, $\mathrm{p}<0.05$ ). IBW (FBW): initial (final) body weight, SGR: specific growth rate. We used 5 different sediment formulations with different sea mud:sand ratios, i.e. 1:0, 3:1, 1:1, 1:3, and 0:1 (represented as M, MMMS, MS, MSSS, and S, respectively)

\begin{tabular}{|c|c|c|c|c|c|}
\hline & M & MMMS & MS & MSSS & $\mathrm{S}$ \\
\hline IBW (g) & $7.49 \pm 0.14$ & $7.56 \pm 0.24$ & $7.61 \pm 0.14$ & $7.47 \pm 0.30$ & $7.46 \pm 0.22$ \\
\hline FBW (g) & $11.49 \pm 0.73^{\mathrm{b}}$ & $13.40 \pm 0.51^{\mathrm{c}}$ & $13.61 \pm 1.09^{c}$ & $11.25 \pm 1.27^{b}$ & $9.52 \pm 0.20^{\mathrm{a}}$ \\
\hline $\operatorname{SGR}(\% d-1)$ & $0.76 \pm 0.15^{b c}$ & $1.02 \pm 0.12^{\mathrm{C}}$ & $1.04 \pm 0.16^{\mathrm{c}}$ & $0.72 \pm 0.20^{\mathrm{b}}$ & $0.44 \pm 0.04^{\mathrm{a}}$ \\
\hline
\end{tabular}

each trophic level (Peterson \& Fry 1987, Gao et al. 2006, Sarà 2007, Sun et al. 2013).

All data were subjected to 1-way analysis of variance (ANOVA) followed by Duncan's test for multiple comparisons to determine the differences in each parameter between different months for each specific group at a significance level of $0.05(p<0.05)$. Prior to statistical analysis, raw data were assessed for normality of distribution and homogeneity of variance using Kolmogorov-Smirnov and Levene's tests, respectively (Zar 1999). Data were presented as mean $\pm \mathrm{SD}(\mathrm{n}=3)$. All statistical analyses were performed using the statistical software SPSS for Windows (Release 22.0).

\section{RESULTS}

\section{Growth performance}

Growth performance of the sea cucumber Apostichopus japonicus on different sediments is shown in Table 2. At the beginning of the experiment, we observed no significant difference in the initial body weights (IBW) of $A$. japonicus between 5 different sediment groups (1-way ANOVA, $F_{4,10}=0.247, \mathrm{p}>$ $0.05)$. After the $70 \mathrm{~d}$ feeding trial, significant differences in final body weight (FBW) $\left(F_{4,10}=11.816, \mathrm{p}<\right.$ $0.05)$ and SGR $\left(F_{4,10}=8.643, \mathrm{p}<0.05\right)$ were observed between different sediment groups. The FBW of $A$. japonicus in sediment groups MS and MMMS were significantly higher than in the sediment groups $\mathrm{M}, \mathrm{S}$, and $\operatorname{MSSS}\left(F_{4,10}=11.816, \mathrm{p}<0.05\right)$. The SGR $\left(\% \mathrm{~d}^{-1}\right)$ of $A$. japonicus in sediment groups MS and MMMS were significantly higher than in the sediment groups $\mathrm{S}$ and MSSS $\left(F_{4,10}=8.643, \mathrm{p}<0.05\right)$. However, no significant differences in the FBW $\left(F_{4,10}=11.816, \mathrm{p}>\right.$ $0.05)$ and SGR $\left(F_{4,10}=8.643, \mathrm{p}>0.05\right)$ between groups MS and MMMS were observed. The FBW $\left(F_{4,10}=\right.$ $11.816, \mathrm{p}<0.05)$ and SGR $\left(F_{4,10}=8.643, \mathrm{p}<0.05\right)$ of $A$. japonicus in sediment group $\mathrm{S}$ were significantly lower than in any other sediment group. There were no significant differences in FBW $\left(F_{4,10}=11.816, \mathrm{p}>\right.$ $0.05)$ and SGR $\left(F_{4,10}=8.643, \mathrm{p}>0.05\right)$ values between sediment groups $\mathrm{M}$ and MSSS.

\section{Carbon stable isotope ratios and nutritional contributions}

Carbon stable isotope ratios $\left(\delta^{13} \mathrm{C}: \%\right)$ and carbon content (\%) of seaweed Sargassum muticum and potential food sources, including sea mud and sand, are listed in Table 3. Isotopic signatures of the seaweed $S$. muticum, sea mud, and sand were significantly different (ANOVA, $F_{2,6}=104.628, \mathrm{p}<0.05$ ).

The $\delta^{13} \mathrm{C}$ values of $A$. japonicus at the end of the experiment were remarkably different from the initial values (Table $3 ; F_{5,12}=23.565, \mathrm{p}<0.05$ ). The mean $\delta^{13} \mathrm{C}$ values of $A$. japonicus in the 5 different sediment groups were all located within those of the corresponding 2 (for sediment groups $\mathrm{M}$ and $\mathrm{S}$ ) or 3 (for sediment groups MS, MMMS, and MSSS) food ingredients after correction for isotope fractionation, indicating the simultaneous absorption of 2 or $3 \mathrm{food}$ sources by A. japonicus.

Table 3. Carbon stable isotope ratios $\left(\delta^{13} \mathrm{C}\right)$ and carbon content of Sargassum muticum, sedimentary ingredients, and sea cucumbers Apostichopus japonicus. Data are presented as mean $\pm \mathrm{SD}(\mathrm{n}=3)$; other details as in Table 2

\begin{tabular}{|lcr|}
\hline Sample & \multicolumn{1}{c|}{$\delta^{13} \mathrm{C}(\%)$} & C content $(\%)$ \\
\hline Food source & & \\
S. muticum & $-16.06 \pm 0.21^{\mathrm{c}}$ & $26.53 \pm 1.03$ \\
Sea mud & $-18.57 \pm 0.44^{\mathrm{b}}$ & $0.26 \pm 0.03$ \\
Sand & $-21.29 \pm 0.60^{\mathrm{a}}$ & $0.04 \pm 0.01$ \\
Sea cucumber & & \\
Initial & $-17.56 \pm 0.09^{\mathrm{a}}$ & $26.45 \pm 2.56$ \\
M & $-16.56 \pm 0.28^{\mathrm{c}}$ & $22.65 \pm 3.92$ \\
MMMS & $-16.23 \pm 0.21^{\mathrm{d}}$ & $24.15 \pm 2.53$ \\
MS & $-16.40 \pm 0.11^{\mathrm{cd}}$ & $25.47 \pm 1.98$ \\
MSSS & $-16.64 \pm 0.21^{\mathrm{c}}$ & $25.94 \pm 1.77$ \\
S & $-17.04 \pm 0.07^{\mathrm{b}}$ & $27.45 \pm 3.11$ \\
\hline
\end{tabular}


Table 4. Nutritional contributions (\%) of Sargassum muticum and sedimentary ingredients to the food uptake of sea cucumber Apostichopus japonicus. Data are presented as mean $\pm \mathrm{SD}(\mathrm{n}=3)$; other details as in Table 2

\begin{tabular}{|c|c|c|c|c|c|}
\hline & M & MMMS & MS & MSSS & $\mathrm{S}$ \\
\hline S. muticum & $86.25 \pm 1.75^{\mathrm{ab}}$ & $94.27 \pm 5.80^{\mathrm{c}}$ & $90.75 \pm 2.25^{\mathrm{bc}}$ & $83.00 \pm 6.06^{\mathrm{a}}$ & $80.23 \pm 1.41^{\circ}$ \\
\hline Sea mud & $13.75 \pm 1.75$ & $1.73 \pm 1.80$ & $1.50 \pm 0.50$ & $5.33 \pm 2.02$ & \\
\hline Sand & & $4.00 \pm 4.00$ & $6.75 \pm 1.75$ & $11.67 \pm 4.04$ & $19.77 \pm 1.41$ \\
\hline
\end{tabular}

Analyses were conducted using the 2-source concentration-weighted isotope mixing model, and the stable isotope mixing model Isosource procedure revealed the relative contribution of $S$. muticum and potential food sources, including sea mud and sand, to the food uptake of $A$. japonicus in the 5 different sediment groups (Table 4). In each of the 5 different sediment groups, the sea mud and sand contributed a mere fraction to the food uptake of sea cucumber relative to $S$. muticum. The proportional contributions of S. muticum to the food uptake of A. japonicus in sediment groups MS and MMMS were significantly higher than in groups S and MSSS $\left(F_{4,10}=6.015, \mathrm{p}<\right.$ 0.05 ), while no significant differences in the proportional contributions of $S$. muticum between sediment groups MS and MMMS were observed $\left(F_{4,10}=6.015\right.$, $\mathrm{p}>0.05)$. The seaweed $S$. muticum contributed more in sediment group MMMS than in group $\mathrm{M}\left(F_{4,10}=\right.$ $6.015, \mathrm{p}<0.05)$. However, the proportional contributions of $S$. muticum in sediment groups MS and M showed similar values $\left(F_{4,10}=6.015, \mathrm{p}>0.05\right)$.

\section{Sedimentary TN, TC, and TOC content}

Significant temporal decreases in TN content of sediment groups $\mathrm{M}\left(F_{3,8}=18.935, \mathrm{p}<0.05\right)$, MS $\left(F_{3,8}=3.290, \mathrm{p}<0.05\right), \operatorname{MSSS}\left(F_{3,8}=6.415, \mathrm{p}<0.05\right)$, and MMMS $\left(F_{3,8}=10.115, \mathrm{p}<0.05\right)$ were observed over the $8 \mathrm{wk}$ experimental period (Fig. 1). In Week 8, TN content of sediment groups $\mathrm{M}\left(F_{3,8}=18.935\right.$, $\mathrm{p}<0.05), \operatorname{MS}\left(F_{3,8}=3.290, \mathrm{p}<0.05\right), \operatorname{MSSS}\left(F_{3,8}=\right.$ $6.415, \mathrm{p}<0.05)$, and MMMS $\left(F_{3,8}=10.115, \mathrm{p}<0.05\right)$ was significantly lower than the corresponding initial content in Week 0. In contrast, the sedimentary TN content of sediment group S did not show significant temporal changes throughout the experimental period $\left(F_{3,8}=0.841, \mathrm{p}>0.05\right)$.

Over the 8 wk experimental period, we observed significant increases in the TC content in sediment groups $\mathrm{M}\left(F_{3,8}=7.071, \mathrm{p}<0.05\right), \mathrm{S}\left(F_{3,8}=10.934, \mathrm{p}<\right.$ $0.05)$, and MSSS $\left(F_{3,8}=31.320, \mathrm{p}<0.05\right.$; Fig. 2$)$. A significant declining trend in TC content was found in sediment group MS $\left(F_{3,8}=3.976, \mathrm{p}<0.05\right)$, while no significant temporal changes occurred in TC content of sediment group MMMS throughout the experimental period $\left(F_{3,8}=1.415, \mathrm{p}>0.05\right)$.

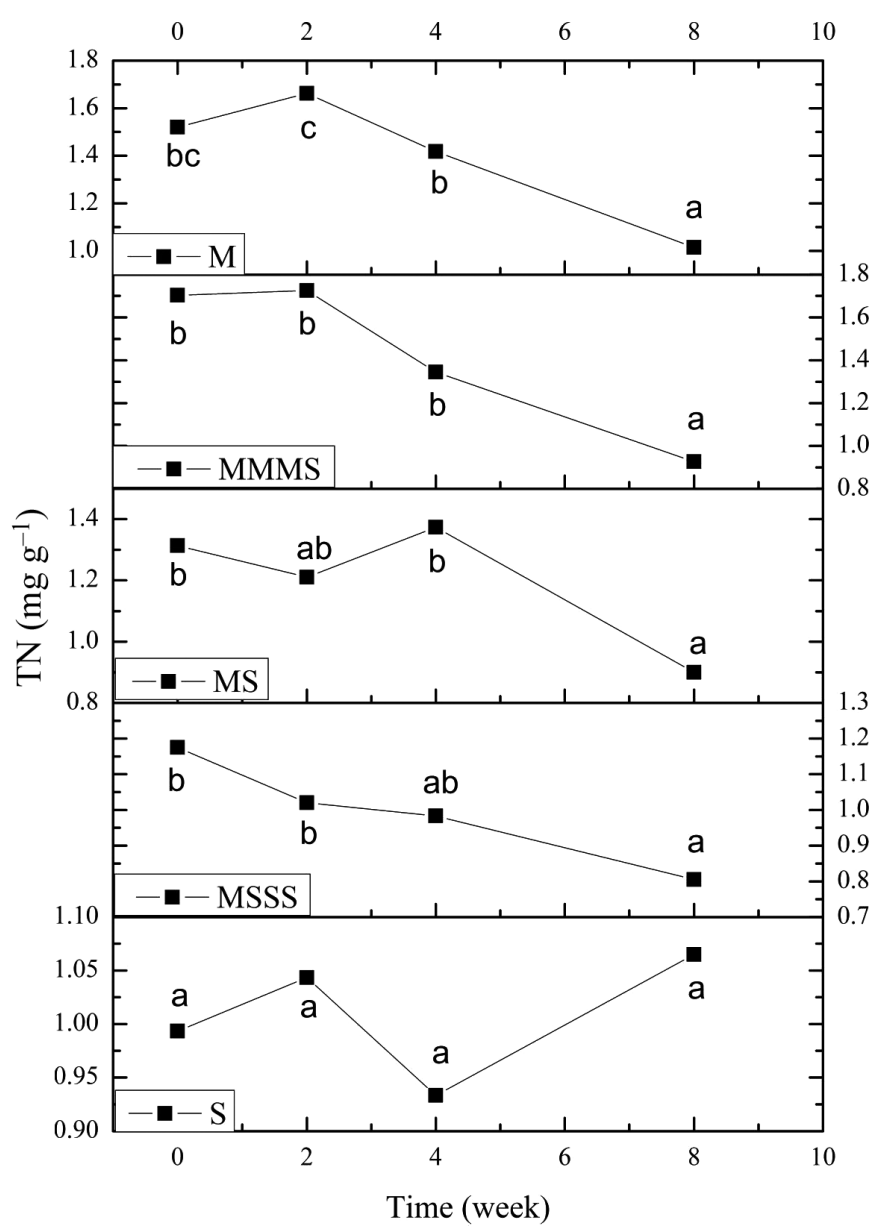

Fig. 1. Temporal changes in sedimentary total nitrogen (TN) content of different sediment treatments during the sea cucumber Apostichopus japonicus culturing experiment. Different letters in the same block mean significant differences between different sampling time points for each specific group (ANOVA with Duncan's test for multiple comparisons, $p<0.05$ ). We used 5 different sediment formulations with different sea mud:sand ratios, i.e. 1:0, 3:1, 1:1, 1:3, and 0:1 (represented as M, MMMS, MS, MSSS, and $\mathrm{S}$, respectively). Note different scales on the $y$-axes 


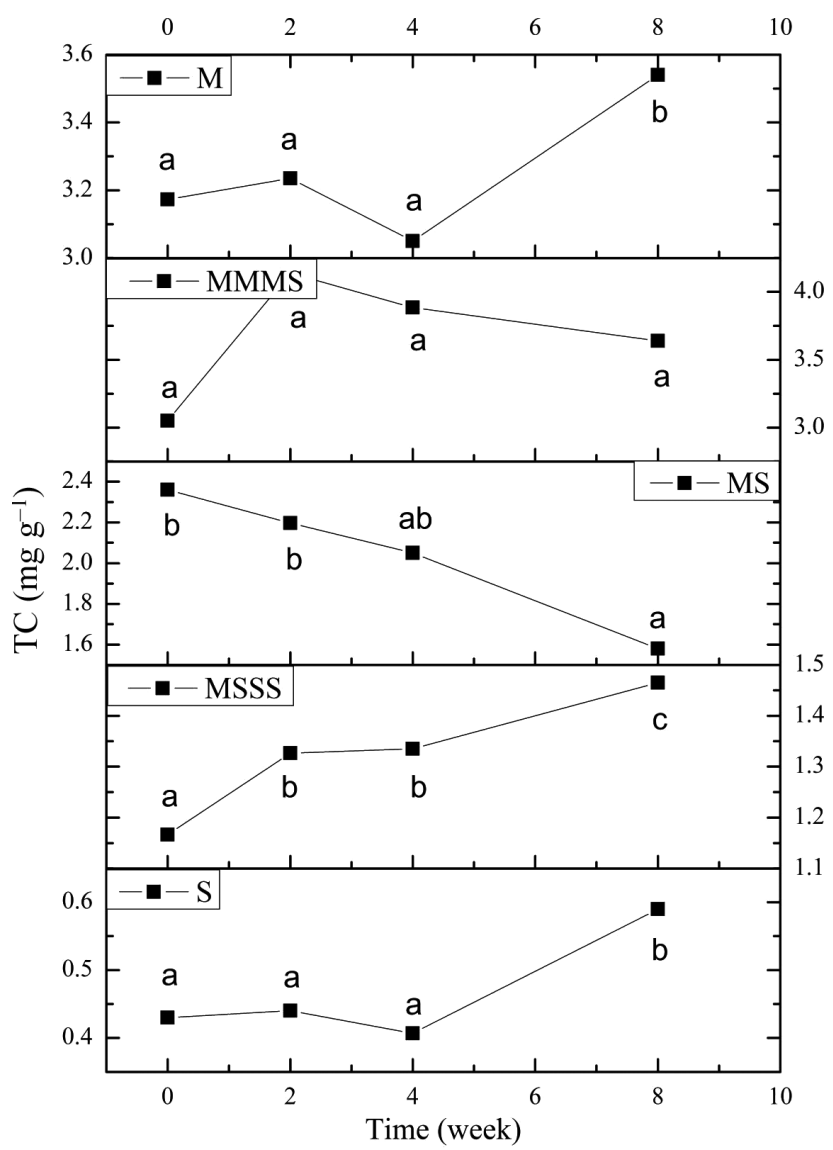

Fig. 2. Temporal changes in total carbon (TC). Details as in Fig. 1

The TOC content of sediment groups $\mathrm{MS}\left(F_{3,8}=\right.$ 2.474, $\mathrm{p}<0.05)$ and MMMS $\left(F_{3,8}=34.726, \mathrm{p}<0.05\right)$ significantly decreased over the $8 \mathrm{wk}$ experimental period (Fig. 3). The TOC content of sediment group $\mathrm{S}$ increased significantly with time $\left(F_{3,8}=12.838, \mathrm{p}<\right.$ $0.05)$; in contrast, no significant temporal changes occurred in the TOC content of sediment groups $\mathrm{M}$ $\left(F_{3,8}=0.367, \mathrm{p}>0.05\right)$ and $\operatorname{MSSS}\left(F_{3,8}=0.047, \mathrm{p}>\right.$ 0.05).

\section{$\mathrm{NH}_{4}{ }^{+}$and $\mathrm{NO}_{3}{ }^{-}$content in sediment}

Significant temporal decreases in $\mathrm{NH}_{4}{ }^{+}$content of sediment groups $\mathrm{MS}\left(F_{3,8}=3.128, \mathrm{p}<0.05\right)$ and MMMS $\left(F_{3,8}=5.150, \mathrm{p}<0.05\right)$ were observed (Fig. 4$)$. In Week 8, the sedimentary $\mathrm{NH}_{4}{ }^{+}$content of sediment groups $\mathrm{MS}\left(F_{3,8}=3.128, \mathrm{p}<0.05\right)$ and $\mathrm{MMMS}\left(F_{3,8}=\right.$ $5.150, \mathrm{p}<0.05)$ was significantly lower than the corresponding initial values in Week 0 . However, no significant temporal changes were found in the $\mathrm{NH}_{4}^{+}$ content of sediment groups $\mathrm{M}\left(F_{3,8}=0.366, \mathrm{p}>0.05\right)$

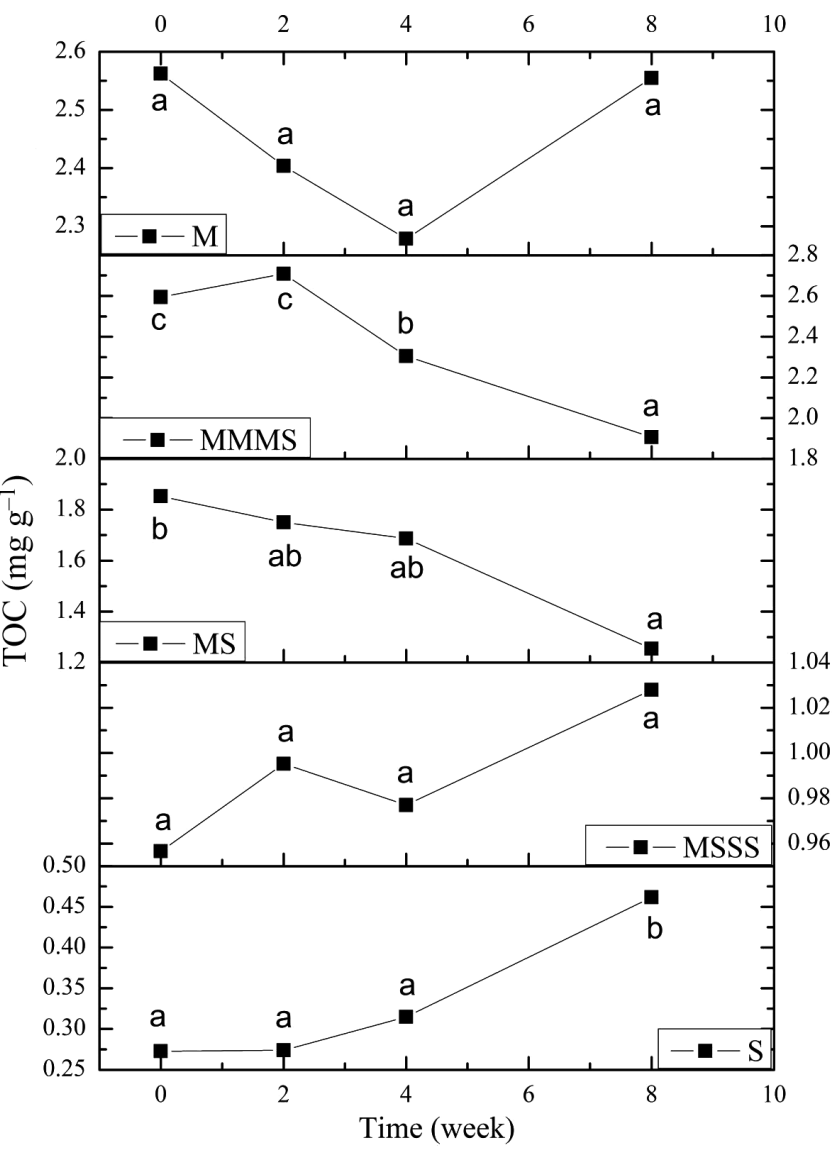

Fig. 3. Temporal changes in total organic carbon (TOC). Details as in Fig. 1

and $\operatorname{MSSS}\left(F_{3,8}=0.579, \mathrm{p}>0.05\right)$ throughout the experimental period ( $\mathrm{p}>0.05$ ). The $\mathrm{NH}_{4}{ }^{+}$content of sediment group $\mathrm{S}$ in Weeks 4 and 8 was significantly higher than in Week $0\left(F_{3,8}=58.754, \mathrm{p}<0.05\right)$. Although no significant difference was observed between the $\mathrm{NH}_{4}{ }^{+}$content of sediment group $\mathrm{S}$ in Weeks 4 and $8\left(F_{3,8}=58.754, \mathrm{p}>0.05\right)$, the $\mathrm{NH}_{4}{ }^{+}$content of sediment group $\mathrm{S}$ in Weeks 4 and 8 was significantly higher than in Week $0\left(F_{3,8}=58.754, \mathrm{p}<0.05\right)$. The temporal changes implied a significant increasing trend with time $\left(F_{3,8}=58.754, \mathrm{p}<0.05\right)$.

We observed significant temporal increases in $\mathrm{NO}_{3}{ }^{-}$content of sediment groups $\mathrm{M}\left(F_{3,8}=3.959, \mathrm{p}<\right.$ $0.05), \mathrm{S}\left(F_{3,8}=13.747, \mathrm{p}<0.05\right)$, and $\operatorname{MMMS}\left(F_{3,8}=\right.$ 13.957, p $<0.05$; Fig. 5). The $\mathrm{NO}_{3}{ }^{-}$content of sediment groups MS $\left(F_{3,8}=14.474, \mathrm{p}<0.05\right)$ and MSSS $\left(F_{3,8}=11.332, \mathrm{p}<0.05\right)$ initially increased over time to a maximum value in Week 4 , then decreased significantly $\left(F_{3,8}=14.474, \mathrm{p}<0.05 ; F_{3,8}=11.332, \mathrm{p}<0.05\right)$. The $\mathrm{NO}_{3}{ }^{-}$content of sediment groups $\mathrm{MS}\left(F_{3,8}=\right.$ $14.474, \mathrm{p}<0.05)$ and $\operatorname{MSSS}\left(F_{3,8}=11.332, \mathrm{p}<0.05\right)$ in Week 8 was significantly lower than those in Week 4. 


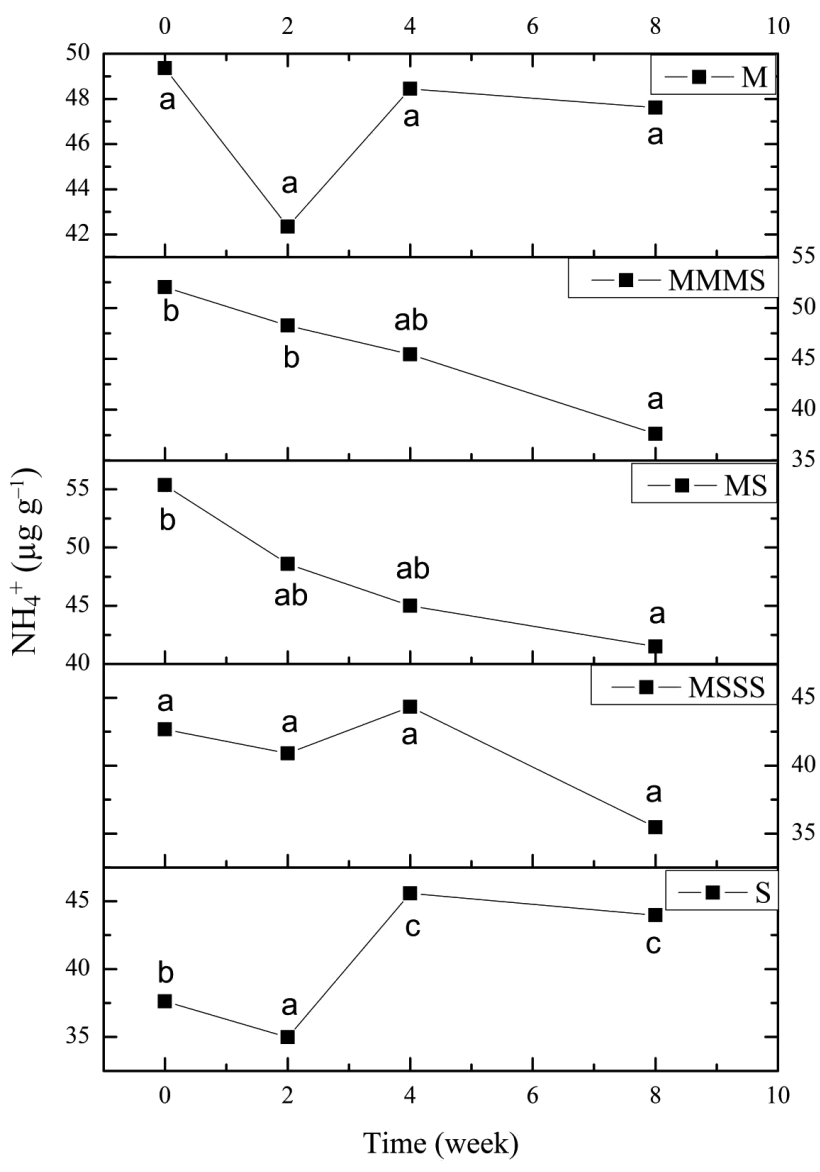

Fig. 4. Temporal changes in $\mathrm{NH}_{4}{ }^{+}$. Details as in Fig. 1

\section{DISCUSSION}

\section{Growth performance and nutritional contribution}

Previous studies have demonstrated that the half-life of carbon isotopic turnover in the body tissue of the sea cucumber Apostichopus japonicus (weighing $5.14 \pm 0.17 \mathrm{~g}$ and $15.30 \pm 0.43 \mathrm{~g}$ ) was 21.39 and $54.15 \mathrm{~d}$, respectively (Sun et al. 2013). Hence, in the present experiment, A. japonicus $(7.49 \pm 0.23 \mathrm{~g})$ completed its carbon isotopic turnover after a feeding trial of $70 \mathrm{~d}$, and the shifts in $\delta^{13} \mathrm{C}$ values of $A$. japonicus toward those of the corresponding diets after isotopic fractionation correction were pronounced. The significant temporal changes indicated the incorporation of potential food items and subsequent isotopic effects on $A$. japonicus. Results from mixing model analyses revealed the relative contributions of the seaweed Sargassum muticum, sea mud, and sand to the food uptake of A. japonicus in 5 different sediment groups.

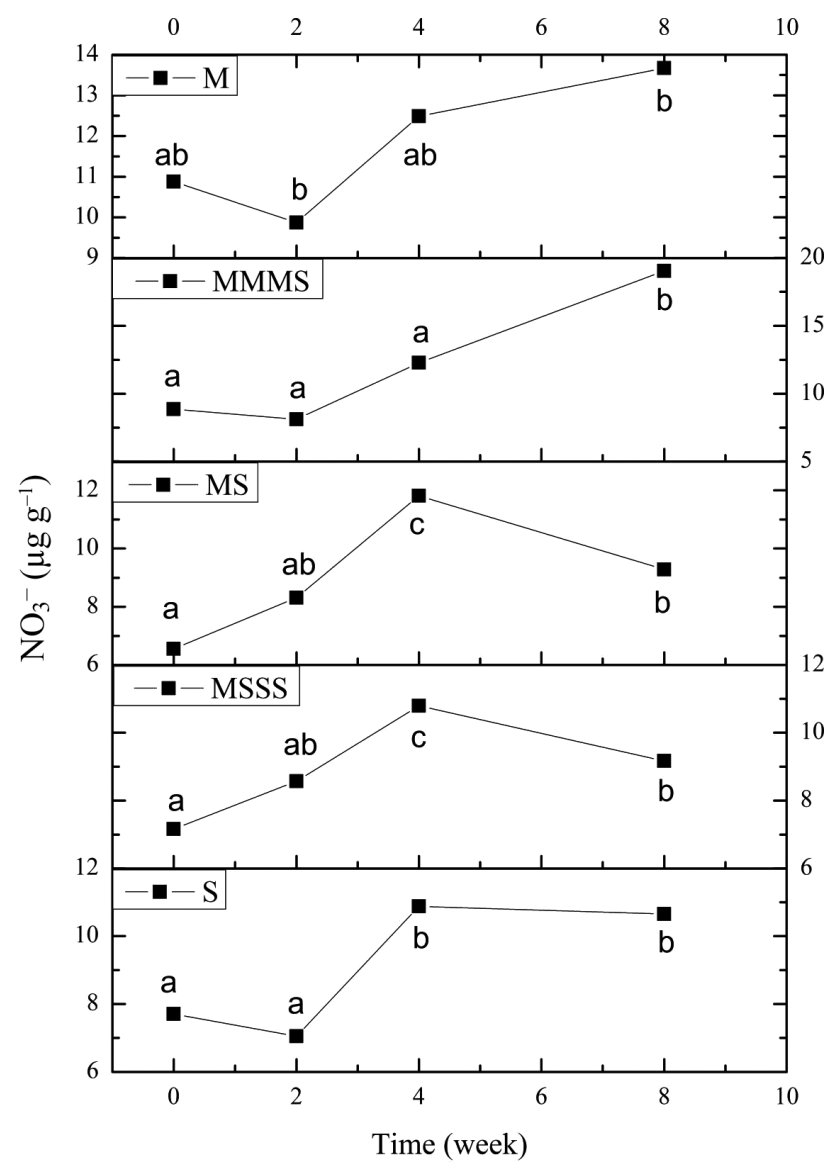

Fig. 5. Temporal changes in $\mathrm{NO}_{3}{ }^{-}$. Details as in Fig. 1

Significant differences in proportional contributions of $S$. muticum and growth performance of sea cucumber between sediment groups MMMS, MS, and $M$ might illustrate that the coarse sediment in groups MMMS and MS could effectively improve the feeding and absorption of $S$. muticum by sea cucumber and subsequently enhance the growth and production of sea cucumber to a greater extent than the pure muddy sediment in group $M$. In each sediment group, the sea mud and sand contributed a mere fraction to the food uptake of sea cucumber relative to $S$. muticum, which was consistent with the proportional contributions of sea mud and yellow mud (terrestrial soil obtained from the freshwater pond) to the food uptake of sea cucumber determined by Jin et al. (2013). The nutritional value of sediment was low, as only a small proportion was readily assimilable, and a large fraction was refractory and not available to most consumers (Heip et al. 1995, MacIntyre et al. 1996, Venturini et al. 2012). Therefore, sediment might help in some other vital functions, not just as a food source (Dar \& Ahmad 2006, Zhao \& Yang 2010). 
Previous studies have indicated that $A$. japonicus preferentially selects habitats with a high proportion of coarse particles (Zhao 2010). A similar preference has been reported in other holothurian species. Dar (2004) observed a strong selective behavior in the feeding habits of some holothurians in the Red Sea: Holothuria atra, Bohadschia marmorata, and H. leucospilota scavenge through coarse sediments much more than through medium or fine grained sediment. Unstable muddy areas like the shipping channels in Hamilton or St. George's Harbours or the deep areas of Harrington Sound in Bermuda had no holothurians (Sloan \& von Bodungen 1980). During the contraction/motion process, which regulates the dynamics of sea cucumbers, the tube feet require stable points on the surface to enable suction. Fine particles are probably unsuitable to provide enough surface area for effective suction. Sea cucumbers therefore might find locomotion more difficult on soft muddy sediments than on coarse sediment (Sloan \& von Bodungen 1980, Dar \& Ahmad 2006, Zhao \& Yang 2010). Coarse sediment might also help in the digestion process (Dar \& Ahmad 2006).

Although A. japonicus preferentially selected coarse sediment, likely owing to important functions in motion and digestion processes, the proportional contributions of $S$. muticum and the growth performance of sea cucumber in sediment groups MSSS and $\mathrm{S}$ was much lower than in sediment groups MS and MMMS. An excessively high proportion of sand might have negative effects on the feeding and assimilation of $S$. muticum, and could retard the growth and production of sea cucumber.

As noted by Mezali \& Soualili (2013), H. (Panningothuria) forskali and $H$. (Platyperona) sanctori show a preference for fine sediments. A. japonicus also generally selected fine particles $(<0.08 \mathrm{~mm})$ rather than coarse particles (Zhao \& Yang 2010). Furthermore, several studies focused on particle selection by other deposit feeders, including polychaetes (Whitlatch 1974, 1976, Hylleberg 1975, Cadee 1976), amphipods (Fenchel et al. 1975), sipunculids (Hansen 1978), gastropods (Fenchel et al. 1975), bivalves (Reid \& Reid 1969, Hylleberg \& Gallucci 1975), and freshwater oligochaetes (Davis 1974, Meadows \& Bird 1974, Kikuchi \& Kurihara 1977, Taghon et al. 1980). In most studies, small grains were preferentially ingested. This is understandable given the higher surface area to volume ratios for the smaller particles. As the surface area to volume ratios increase with small particles, the surface area to which organic matter can adsorb increases as well (Belbachir et al. 2014). However, since bacterial quantity per unit surface area of sedimentary particles seems surprisingly constant (Dale 1974, Hargrave 1972), the total amount of bacteria, being directly related to the total surface area of the sedimentary particles, increases with smaller particle size (Newell 1965, Odum \& de la Cruz 1967, Fenchel 1970, Hargrave 1972, Dale 1974). Hence, the smaller particles represented more food per unit volume and were selectively ingested by sea cucumbers. Another possible reason for the selective ingestion of fine particles rather than coarse (sand) particles was the smooth surface of sand, which was difficult for organic matter to adhere to.

Accordingly, in our experiment, sea cucumbers tended to select the smaller particles (sea mud) with more available food in order to gain a maximum amount of energy with a minimum loss of time and minimum loss of energy, which is consistent with optimal foraging theory (Taghon et al. 1978, Taghon 1982). Coarse sand particles might help in the digestion process and motion process, which shortens foraging time and reduces energy consumption during motion more effectively than pure, muddy sediment. The sediments in groups MMMS and MS could provide enough small sea mud particles for selective ingestion by sea cucumbers as well as coarse sand particles for mechanically assisting locomotion.

\section{Temporal changes in organic and nutrient loads}

Sea cucumbers are considered the most important macrofaunal consumers and processors of surface sediments in a wide variety of sub-tidal marine systems. Previous studies have shown that sea cucumbers can reduce nutrient and organic content in sediment through consumption, digestion, physical displacement, and bioturbation (Moriarty et al. 1985, Levin 1999, Uthicke 1999, 2001, Roberts et al. 2000, Michio et al. 2003). Given the environmental advantages of sea cucumbers for sediment, A. japonicus can act as an important scavenger with great potential for bioremediation which could effectively remove the aquaculture waste and inhibit the accumulation of sedimentary nutrients and organic matter in aquaculture systems (Kang et al. 2003, IşgörenEmiroğlu \& Günay 2007, Ren et al. 2010, Yuan et al. 2012).

Temporal changes in $\mathrm{TN}, \mathrm{TC}, \mathrm{TOC}$, and nutrient content of different sediment groups indicated that the sea cucumbers in sediment groups MS and MMMS could effectively stop the accumulation of organic matter and ammonium by means of ingestion, digestion, and bioturbation. However, organic 
matter accumulated remarkably in sediment groups $\mathrm{S}, \mathrm{MSSS}$, and $\mathrm{M}$, especially in sediment group $\mathrm{S}$, which showed high ammonium accumulation. $A$. japonicus cultured in groups MSSS, S, and M could not effectively remove the aquaculture waste and inhibit the accumulation of sedimentary nutrients and organic matter in the aquaculture system. This was probably due to the negative effects on sea cucumber derived from unsuitable sediments in these groups. The sediments in groups $\mathrm{S}$ and MSSS were unable to supply enough small sea mud particles, so the sea cucumbers may have spent more energy and time on foraging, ingestion, and digestion, which probably ultimately would have resulted in starvation. This in turn might reduce overall activity and might represent an adaptation of sea cucumbers to minimize the use of metabolic reserves (Newell 1973, Féral 1985). During starvation, the bioturbation derived from sea cucumbers in sediment groups S and MSSS was weaker than in the sediment groups MMMS and MS. Although the sediment in group $M$ could provide enough small sea mud particles, the absence of coarse sand particles made it difficult for sea cucumbers to move normally (Sloan \& von Bodungen 1980, Dar \& Ahmad 2006, Zhao \& Yang 2010), which may subsequently have interfered with foraging, ingestion, and bioturbation. Hence, the sea mud:sand ratios in sediments of groups $S$, MSSS, and $M$ were unsuitable for sea cucumber aquaculture in terms of ecological benefits. The unsuitable sediment formulations significantly interfered with the bioremediation of A. japonicus and damaged the environmental sustainability in the aquaculture system.

In conclusion, sediments with suitable sea mud: sand ratios ranging from 1:1 to $3: 1$ could provide enough small sea mud particles $(<0.08 \mathrm{~mm})$ that were preferred by $A$. japonicus because of their organic matter and abundant bacterial biomass. These sediment formulations would also include enough sand particles to help during locomotion; thus, sea mud:sand ratios ranging from $1: 1$ to $3: 1$ would provide a sediment range that should lead to the best growth performance. Furthermore, sea cucumbers cultured on these sediments could effectively prevent organic matter and nutrient accumulation. Hence, this sediment composition might be the best choice for sea cucumber culture in aquaculture ponds.

Acknowledgements. This study was funded by the National Natural Science Foundation of China (grant nos. 31672657 and 31372549).

\section{LITERATURE CITED}

Belbachir N, Mezali K, Soualili DL (2014) Selective feeding behaviour in some aspidochirotid holothurians (Echinodermata: Holothuroidea) at Stidia, Mostaganem Province, Algeria. SPC Beche-de-mer Inf Bull 34:34-37

Bremner JM (1965) Inorganic forms of nitrogen. In: Black CA (ed) Methods of soil analysis. American Society of Agronomy, Madison, WI, p 1179-1237

Cadee GC (1976) Sediment reworked by Arenicola marina on tidal flats in the Dutch Wadden Sea. Neth J Sea Res 10:440-460

Chen JX (2004) Present status and prospects of sea cucumber industry in China. In: Lovatelli A, Conand C, Purcell S, Uthicke S, Hamel JF, Mercier A (eds) Advances in sea cucumber aquaculture and management 463. FAO, Rome, p 25-38

Wale NG (1974) Bacteria in intertidal sediments: factors related to their distribution. Limnol Oceanogr 19:509-518

Dar MA (2004) Holothurian role in the marine sediments reworking processes. Sedimentol Egypt 12:173-183

Dar MA, Ahmad HO (2006) The feeding selectivity and ecological role of shallow water holothurians in the Red Sea. SPC Beche-de-mer Inf Bull 24:11-21

*Davis RB (1974) Stratigraphic effects of tubificids in profundal lake sediments. Limnol Oceanogr 19:466-488

Fenchel T (1970) Studies on the decomposition of organic detritus derived from the turtle grass Thalassia testudinum. Limnol Oceanogr 15:14-20

Fenchel T, Kofoed LH, Lappalainen A (1975) Particle size selection of two deposit feeders: the amphipod Corophium volutator and the prosobranch Hydrobia ulvae. Mar Biol 30:119-128

Féral JP (1985) Effect of short-term starvation on the biochemical composition of the apodous holothurian Leptosynapta galliennei (Echinodermata): possible role of dissolved organic material as an energy source. Mar Biol 86: 297-306

Fry B (2006) Stable isotope ecology. Springer Verlag, New York, NY

Gao QF, Shin PKS, Lin GH, Chen SP, Cheung SG (2006) Stable isotope and fatty acid evidence for uptake of organic waste by green-lipped mussels Perna viridis in a polyculture fish farm system. Mar Ecol Prog Ser 317:273-283

* Hansen MD (1978) Nahrung und Freßverhalten bei Sedimentfressern dargestellt am Beispiel von Sipunculiden und Holothurien (Food and feeding behavior of sediment feeders as exemplified by sipunculids and holothurians). Helgol Wiss Meeresunters 31:191-221 (with English abstract)

Hargrave BT (1972) Aerobic decomposition of sediment and detritus as a function of particle surface area and organic content. Limnol Oceanogr 17:583-596

Hauksson E (1979) Feeding biology of Stichopus tremulus, a deposit-feeding holothurian. Sarsia 64:155-160

Heip CHR, Goosen NK, Herman PMJ, Kromkamp J, Middelburg JJ, Soetaert K (1995) Production and consumption of biological particles in temperate tidal estuaries. Oceanogr Mar Biol Annu Rev 33:1-149

* Hylleberg J (1975) Selective feeding by Abarenicola pacifica with notes on Abarenicola vagabunda and a concept of gardening in lugworms. Ophelia 14:113-137

*Hylleberg J, Gallucci VF (1975) Selectivity in feeding by the deposit-feeding bivalve Macoma nasuta. Mar Biol 32: $167-178$ 
Işgören-Emiroğlu D, Günay D (2007) The effect of sea cucumber Holothuria tubulosa (G., 1788) on nutrient and sediment of Aegean sea shores. Pak J Biol Sci 10: 586-589

Jin BC, Dong SL, Tian XL, Wang F, Gao QF, Lin GH, Guan $\mathrm{JH}(2013)$ Using carbon stable isotope ratio $\left(\delta^{13} \mathrm{C}\right)$ to evaluate contribution of artificial feeds to growth of pond cultured juvenile sea cucumber Apostichopus japonicus (Selenka). Shuichan Xuebao 37:269-274

Jumars PA, Self RF (1986) Gut-marker and gut-fullness methods for estimating field and laboratory effects of sediment transport on ingestion rates of deposit-feeders. J Exp Mar Biol Ecol 98:293-310

Kang KH, Kwon JY, Kim YM (2003) A beneficial coculture: charm abalone Haliotis discus hannai and sea cucumber Stichopus japonicus. Aquaculture 216:87-93

Kikuchi E, Kurihara Y (1977) In vitro studies on the effects of tubificids on the biological, chemical and physical characteristics of submerged ricefield soil and overlying water. Oikos 29:348-356

Kitano M, Kurata K, Kozuki Y, Murakami H, Yamasaki T, Yoshida H, Sasayama H (2003) Effects of deposit feeder Stichopus japonicus on algal bloom and organic matter contents of bottom sediments of the enclosed sea. Mar Pollut Bull 47:118-125

Levin VS (1999) Feeding by shallow-water holothuroids (Echinodermata) and its effect on the environment. ELIMOR, St. Petersburg

Liao Y (1980) The aspidochirote holothurians of China with erection of a new genus. In: Jangoux M (ed) Echinoderms: present and past (Proceedings of the European Colloquium on Echinoderms). AA Balkema Publishers, Rotterdam, p 115-120

MacIntyre HL, Geider RJ, Miller DC (1996) Microphytobenthos: the ecological role of the 'Secret Garden' of unvegetated, shallow-water marine habitats. I. Distribution, abundance and primary production. Estuaries 19: 186-201

Meadows PS, Bird AH (1974) Behaviour and local distribution of the freshwater oligochaete Nais pardalis Piguet (Family Naididae). Hydrobiologia 44:265-275

Mezali K, Soualili DL (2013) The ability of holothurians to select sediment particles and organic matter. SPC Bechede-Mer Inf Bull 33:38-43

Michener R, Lajtha K (eds) (2008) Stable isotopes in ecology and environmental science. John Wiley \& Sons, Waco, TX

MOAC (Ministry of Agriculture, China) (2015) China fisheries yearbook, 2014. China Agriculture Publisher, Beijing

Moriarty D (1982) Feeding of Holothuria atra and Stichopus chloronotus on bacteria, organic carbon and organic nitrogen in sediments of the Great Barrier Reef. Mar Freshw Res 33:255-263

* Moriarty DJW, Pollard PC, Hunt WG, Moriarty CM, Wassenberg TJ (1985) Productivity of bacteria and microalgae and the effect of grazing by holothurians in sediments on a coral flat. Mar Biol 85:293-300

Newell R (1965) The role of detritus in the nutrition of two marine deposit feeders, the prosobranch Hydrobia ulvae and the bivalve Macoma balthica. Proc Zool Soc Lond 144:25-45

Newell RC (1973) Factors affecting the respiration of intertidal invertebrates. Am Zool 13:513-528

Odum EP, de la Cruz AA (1967) Particulate organic detritus in a Georgia salt marsh estuarine system. In: Lauff GH (ed) Estuaries. American Association for the Advancement of Science, Washington, DC, p 383-388

* Okorie OE, Ko SH, Go S, Lee S, Bae JY, Han K, Bal SC (2008) Preliminary study of the optimum dietary ascorbic acid level in sea cucumber, Apostichopus japonicus (Selenka). J World Aquacult Soc 39:758-765

* Peterson BJ, Fry B (1987) Stable isotopes in ecosystem studies. Annu Rev Ecol Syst 18:293-320

* Phillips DL (2001) Mixing models in analyses of diet using multiple stable isotopes: a critique. Oecologia 127: 166-170

* Phillips DL, Gregg JW (2003) Source partitioning using stable isotopes: coping with too many sources. Oecologia 136:261-269

*Phillips DL, Koch PL (2002) Incorporating concentration dependence in stable isotope mixing models. Oecologia 130:114-125

Reid RB, Reid A (1969) Feeding processes of members of the genus Macoma (Mollusca: Bivalvia). Can J Zool 47: 649-657

Ren Y, Dong SL, Wang F, Gao QF, Tian XL, Liu F (2010) Sedimentation and sediment characteristics in sea $\mathrm{cu}-$ cumber Apostichopus japonicus (Selenka) culture ponds. Aquacult Res 42:14-21

* Rhoads DC, Young DK (1971) Animal sediment relations in Cape Cod Bay, Massachusetts. 11. Reworking by Molpadja oolitica (Holothuroidea). Mar Biol 11:255-261

Roberts D (1979) Deposit-feeding mechanisms and resource partitioning in tropical holothurians. J Exp Mar Biol Ecol 37:43-56

Roberts D, Gebruk A, Levin V, Manship BAD (2000) Feeding and digestive strategies in deposit-feeding holothurians. Oceanogr Mar Biol Annu Rev 38:257-310

* Sarà G (2007) Sedimentary and particulate organic matter: mixed sources for cockle Cerastoderma glaucum in a shallow pond, Western Mediterranean. Aquat Living Resour 20:271-277

* Sarà G, Scilipoti D, Mazzola A, Modica A (2004) Effects of fish farming waste to sedimentary and particulate organic matter in a southern Mediterranean area (Gulf of Castellammare, Sicily): a multiple stable isotope study $\left(\delta^{13} \mathrm{C}\right.$ and $\left.\delta^{15} \mathrm{~N}\right)$. Aquaculture 234:199-213

Sloan NA (1984) Echinoderm fisheries of the world: a review. In: Proceedings of the Fifth International Echinoderm Conference. AA Balkema, Rotterdam, 109-124

Sloan NA, von Bodungen B (1980) Distribution and feeding of the sea cucumber Isostichopus badionotus in relation to shelter and sediment criteria of the Bermuda platform. Mar Ecol Prog Ser 2:257-264

* Sun ZL, Gao QF, Dong SL, Shin PK, Wang F (2013) Seasonal changes in food uptake by the sea cucumber Apostichopus japonicus in a farm pond: evidence from $\mathrm{C}$ and $\mathrm{N}$ stable isotopes. J Ocean Univ China 12:160-168

*Taghon GL, Self RFL, Jumars PA (1978) Predicting particle selection by deposit feeders: a model and its implications. Limnol Oceanogr 23:752-759

* Taghon GL, Nowell ARM, Jumars PA (1980) Introduction of suspension feeding in spionid polychaetes by high particulate fluxes. Science 210:562-564

Taghon GL (1982) Optimal foraging by deposit-feeding invertebrates: roles of particle size and organic coating. Oecologia (Berlin) 52:295-304

Uthicke S (1999) Sediment bioturbation and impact of feeding activity of Holothuria (Halodeima) atra and Stichopus 
chloronotus, two sediment feeding holothurians, at Lizard Island, Great Barrier Reef. Bull Mar Sci 64:129-141

Uthicke S (2001) Nutrient regeneration by abundant coral reef holothurians. J Exp Mar Biol Ecol 265:153-170

Uthicke S, Klumpp DW (1998) Microphytobenthos community production at a near-shore coral reef: seasonal variation and response to ammonium recycled by holothurians. Mar Ecol Prog Ser 169:1-11

*Venturini N, Pita AL, Brugnoli E, García-Rodríguez F and others (2012) Benthic trophic status of sediments in a metropolitan area (Rio de la Plata estuary): linkages with natural and human pressures. Estuar Coast Shelf Sci 112: 139-152

Wen B, Gao QF, Dong SL, Hou YR, Yu HB, Li WD (2016) Uptake of benthic matter by sea cucumber Apostichopus japonicus (Selenka): insights from carbon stable isotopes and fatty acid profiles. J Exp Mar Biol Ecol 474:46-53

Whitlatch RB (1974) Food-resource partitioning in the deposit-feeding polychaete Pectinaria gouldii. Biol Bull (Woods Hole) 147:227-235

Whitlatch RB (1976) Methods of resource allocation in marine deposit-feeding invertebrates. Am Zool 16:195

Wiedemeyer WL (1994) Biology of small juveniles of the tropical holothurian Actinopyga echinites: growth, mortality, and habitat preferences. Mar Biol 120:81-93

Xia S, Yang H, Li Y, Liu S, Zhou Y, Zhang L (2012) Effects of different seaweed diets on growth, digestibility, and ammonia-nitrogen production of the sea cucumber Apostichopus japonicus (Selenka). Aquaculture 338-341:304-308

Y Yang H, Yuan X, Zhou Y, Mao Y, Zhang T, Liu Y (2005) Effects of body size and water temperature on food consumption and growth in the sea cucumber Apostichopus

Editorial responsibility: Gianluca Sará,

Palermo, Italy japonicus (Selenka) with special reference to aestivation. Aquacult Res 36:1085-1092

Yingst JY (1976) The utilization of organic matter in shallow marine sediments by an epibenthic deposit-feeding holothurian. J Exp Mar Biol Ecol 23:55-69

Yokoyama H (2013) Growth and food source of the sea cucumber Apostichopus japonicus, cultured below fish cages - potential for integrated multi-trophic aquaculture. Aquaculture 372-375:28-38

Yuan XT (2005) Studies on physio-ecology and bioremediation of the sea cucumber, Apostichopus japonicus (Selenka). PhD dissertation, Chinese Academy of Science, Qingdao (in Chinese with English abstract)

Yuan XT, Wang LL, Yang HS, Yang DZ (2012) Bio-scavenging on self-pollutants with different carbon and nitrogen loads from a raft bivalve and macroalgae culture system by the deposit-feeding sea cucumber Apostichopus japonicus (Selenka). Shengtaixue Zazhi 31:374-380 (in Chinese with English abstract)

Zamora LN, Yuan X, Carton AG, Slater MJ (2016) Role of deposit-feeding sea cucumbers in integrated multitrophic aquaculture: progress, problems, potential and future challenges. Rev Aquacult (in press), doi:10.1111/ raq. 12147

Zar JH (1999) Biostatistical analysis. Prentice Hall, Upper Saddle River, NJ

Zhao P, Yang HS (2010) Selectivity of particle size by sea cucumber Apostichopus japonicus in different culture systems. Mark Sci 34:11-16

Zhou W, Wang JJ, Jia LU, Wang XB (2008) The selectivity of sea cucumber Apostichopus japonicus for dietary sand particle sizes. J Dalian Fish Univ 23:446-450

Submitted: November 28, 2016; Accepted: May 21, 2017

Proofs received from author(s): July 27, 2017 